\title{
A TALE OF TWO COUNTRIES: NATION BUILDING AND SECURITY CHALLENGES IN MYANMAR AND INDONESIA ${ }^{1}$
}

For most of the former European colonies of South and Southeast Asia, the end of the Second World War was also the beginning of the end of colonial rule. With independence came the challenge of unifying disparate ethnic, religious and linguistic communities into cohesive nations - a challenge that some countries met more successfully than others. The price of failure could be high - hundreds of thousands were killed, and many millions displaced in 1947, as inter-communal conflicts tore British India apart. Indonesia declared independence in 1945 (a declaration not recognised by the country's Dutch colonial rulers until 1949), while Burma (as Myanmar was then known) was granted independence by Britain in 1948. Both countries were able to avoid tragedies on the scale of the Indian Partition. Nevertheless, nation-building has been a difficult and as yet uncompleted process, the source of continuing challenges to national security. This article looks at the situation in the two countries, traces the origins of some of the current problems, and attempts to explain why Indonesia has generally been more successful in this respect than Myanmar, despite the similarities in the initial situations of the two countries.

\section{MYANMAR: STILL STRUGGLING TO ACHIEVE NATIONAL UNITY}

Myanmar is mostly Buddhist ( $88 \%$ of the population, according to the 2014 census (Govt Publishes, 2016), with significant minorities of Christians (6\%) and Muslims (4\%). Ethnicity is such a sensitive issue in the country that the government has yet to release census data on the subject, but it is estimated (Central, 2017) that $68 \%$ are ethnic Bamar (Burman), with Shan, Karen and Rakhine minorities accounting for 9\%, $7 \%$ and 4\% respectively. Altogether, the 1982 Citizenship Law recognises 135 ethnic minorities, not including the Rohingya people of Rakhine state.

${ }^{1}$ The content of this document is the sole responsibility of the author and any opinions expressed therein do not necessarily represent the official position of the European Parliament. 


\section{A long-standing history of violence between Myanmar armed forces and ethnic minorities}

Relations between the Bamar majority and the ethnic minorities were already difficult before independence; the Second World War pitched the Bamar majority, who allied themselves with the Japanese occupiers in the hope of winning independence from the British, against most of the minorities. Tensions continue to bedevil Myanmar, which has never known lasting peace during its seventy years of independence. The latest Rohingya crisis has focused international attention on the country; since August 2017 nearly 700,000 Muslim Rohingya have fled horrific violence in the country. Reportedly, thousands have been killed or raped, and hundreds of villages burned down by the army, sometimes in collusion with Buddhist mobs. Sadly, such atrocities are nothing new; in 1978, 1991 and 2016 hundreds of thousands fled military crackdowns, while 2012 saw mob violence. Myanmar and neighbouring Bangladesh have signed an agreement to repatriate some of the refugees, but persecution in Myanmar continues amid accusations of genocide (Myanmar events, 2018), and there are no prospects of the Rohingya being able to safely live in the region which their ancestors have inhabited for generations.

Brutal attacks on Muslim Rohingya raise the risks of Islamist terrorism. The two latest waves of violence (in October 2016 and August 2017) were sparked when rebels from the Arakan Rohingya Salvation Army (ARSA), a Rohingya insurgent group, attacked police and border guards. For the time being, the terrorist threat remains limited; there is no evidence that ARSA has more than basic skills and weapons, nor that it has links to Al-Qaida or ISIL/Da'esh. Nevertheless, ARSA commands widespread support among Rohingya refugees in Bangladeshi camps (In Bangladesh, 2017), and with international outrage among Muslims at the plight of the Rohingya, Islamic State has threatened attacks on the country (Myanmar faces, 2017).

Myanmar's remaining ethnic minorities are at least legally recognised, and not therefore discriminated against as non-citizens, as most Rohingya are. However, the situation for many of them is very difficult. The country's longest running conflict was a 62year insurgency by the Karen National Liberation Army, ended by a ceasefire in 2012. ${ }^{2}$ Government troops have also fought ethnic armed groups representing the Shan, Mon, Arakan, Kokang, Kachin and Palaung minorities, among others. The number of deaths directly related to such ethnic conflicts between 1989 and 2016 has been estimated at over $17,000,{ }^{3}$ with a peak in fighting in the $1990 \mathrm{~s}$, followed by a renewed surge in 2011 and 2012, which has since subsided but not ended. Fighting continues in the north of the country; Amnesty International claims (Myanmar: Ethnic, 2017) that in the first half of 2017, 100,000 civilians from northern Myanmar lost their homes; there have been torture and extrajudicial executions. Control of some ethnic regions is shared by government troops and insurgents; Wa State, a Wales-sized region on the Chinese border, escapes government rule altogether. The lack of state authority creates ideal conditions for

${ }^{2}$ However, sporadic fighting continues; Karen representatives claim that in March 2018 over 1500 villagers fled Myanmar army raids. See: Burma/Myanmar, 2018.

${ }^{3}$ According to the Uppsala Conflict Data Programme, http://ucdp.uu.se/?id=1\#country/775 (12.04.2018). 
criminal activities including drug and human trafficking. Meanwhile, the country's vast natural resource wealth (for example, one estimate (Jade, 2015) puts the value of jade extracted in 2014 at US\$31 billion) is being plundered by the army, ethnic insurgents and criminal gangs, sometimes in collusion with one another, instead of benefiting the impoverished ethnic areas where much of it is concentrated.

\section{Recent developments: national ceasefire talks and democratic reforms have only brought limited progress}

In an effort to end conflicts in ethnic regions, the government has signed bilateral ceasefires with several ethnic armed groups. The aim is to reach a national ceasefire agreement embracing all the ethnic armed groups, and on the basis of that, a political settlement that would meet ethnic minority demands for greater autonomy. At present, seven of the largest minorities have their own "ethnic states," but in practice, state governments have very few powers and financial resources of their own. Progress towards a lasting peace has been slow, with several armed groups refusing to sign up to a draft national ceasefire agreed in 2015. In August 2016, State Counsellor Aung San Suu Kyi opened the first session of the 21st Century Panglong peace conference, named after the 1947 Panglong conference which Suu Kyi's father, Aung San, hoped would settle the ethnic minority issue in the soon-to-be independent state. To date, government and ethnic negotiators have agreed in principle to move towards a federal state, but not all ethnic groups are participating, and important sticking points remain - for example, the government's demand for integration of ethnic armed groups into a federal army, and ethnic insistence on the right to secede from the country.

In 2008, the brutal military junta which had ruled the country since 1962 prepared the way for political reforms by adopting a new constitution, based on which a nominally civilian government (in fact, mostly comprising former generals) was elected. A further important step forward came in the 2015 elections, in which former opposition leader Aung San Suu Kyi's National League for Democracy (NLD) scored an overwhelming victory. Myanmar's democratic transition raised hopes of an end to the country's simmering ethnic tensions. Those hopes have been disappointed; as the ethnic cleansing of the Rohingya and the fighting in Northern Myanmar show, the government is utterly powerless to restrain the military. The causes of its impotence lie in the 2008 Constitution, under which the commander-in-chief appoints defence, home affairs and border affairs ministers, as well as one-quarter of parliament seats, giving him an effective veto over any constitutional changes. Armed forces personnel answer to military courts only, and in the event of a state of emergency, the military is empowered "to take over and exercise State sovereign power."

In some ways, greater political freedoms have even exacerbated tensions, by making it easier for radical Buddhists - such as virulent monk Wirathu and the populist $\mathrm{Ma} \mathrm{Ba}$ Tha movement - to stir up hatred of religious minorities, Muslims in particular. There have been attacks not only on Rohingya but also other Muslims; in 2013 over 40 were killed in central Myanmar after rioters burned down Muslim-owned shops and houses. Caught between continuing military brutality on the one hand, and rising 
religious intolerance on the other, Aung San Suu Kyi's government appears neither willing nor able to stand up for the country's ethnic and religious minorities. Suu Kyi's NLD did not field a single Muslim candidate in the 2015 elections, and it has not criticised the military for its operations against the Rohingya and other ethnic minorities.

\section{INDONESIA'S PROGRESS TOWARDS STABLE DEMOCRACY}

Like Myanmar, Indonesia is dominated by one main religion (Islam, with $87 \%$ of the population), with religious minorities including Protestant (7\%), Catholic (2.9\%), Hindu (1.7\%) and Buddhist (1.2\%) (Indonesia, 2010). In contrast to Myanmar, no single ethnic group constitutes a majority; the largest minority is Javanese (40\%), followed by Sundanese (15\%), Malay (3.7\%) and Batak (3.6\%). Unlike Myanmar, the national language (Bahasa Indonesia) is not that of the main ethnic minority, but is based on that of the much smaller Malay minority.

\section{The post-independence period: external and internal threats to peace and stability}

Given its even greater diversity, and the fact that the country as a whole had never been united under a single ruler before the pre-colonial period (unlike Myanmar, which for much of its history had existed more or less within its current borders), Indonesia's nation-building challenge was a particularly daunting one. Since independence, the country has faced serious threats to its peace and stability. Indonesia's darkest hour came in 1965-1966, when armed forces massacred half a million or more suspected Communists. Despite an unprecedented symposium (Truth, 2016) on the subject in April 2016, the country has yet to come fully to terms with the horrors of that event; no attempt has been made to bring surviving perpetrators of atrocities to justice, and the currently serving defence minister has even argued (Indonesia's, 2016) that Communists "deserved to die."

During the first decades of its existence, Indonesia waged an undeclared war with neighbouring Malaysia (the Konfrontasi, 1963-1966), and invaded Dutch-ruled Papua (1961) and Portuguese-ruled East Timor (1975). Indonesia's relations with its neighbours improved considerably in 1967 after it became a founder member of the Association of Southeast Asian Neighbours (ASEAN). However, violence continued on the domestic front due to a 28-year-long insurgency in the western province of Aceh, in parallel with bloody conflicts in the annexed territories of East Timor and Papua.

\section{After initial outbreaks of violence, democracy brings greater stability}

The 1997 Asian financial crisis and resulting economic downturn triggered an uprising which toppled Suharto in 1998. Elections held the following year restored multiparty democracy. Unfortunately, greater political freedoms lifted the lid on a series of 
inter-ethnic and -religious conflicts which had been largely suppressed under Suharto. Thousands were killed in anti-Chinese riots (Jakarta, Java, Sumatra; 1998), clashes between Muslims and Christians in the eastern Maluku islands starting in 1999, and the Sampit massacres in Indonesian Borneo.

Despite these problems, democracy appears to have firmly taken root in Indonesia. Successive elections, assessed by international observers as mostly free and fair, have enabled a peaceful alternation of power. The role of the military has also been curbed; in 2004 it gave up its power to appoint one-fifth of parliamentary seats (Military, 2004), and active military personnel are now barred from standing in elections. It is true that the armed forces still retain considerable influence, due to the continued presence of former senior military officers in Indonesian politics (three ministers in the current government, as well as ex-president Susilo Bambang Yudhoyono (2004-2014) and Prabowo Subianto, runner-up in the 2014 presidential election), as well as to the Army's involvement in implementing civilian agricultural and road-building projects (In the name, 2017). Nevertheless, that influence has gradually diminished; the December 2017 appointment of Hadi Tjahjanto as head of the Indonesian National Armed Forces, seen as a loyal supporter of the country's president without political ambitions (Indonesia's, 2018), was the latest step forward to consolidating civilian control over the military.

In parallel with this progress towards civilian democracy, the security situation has gradually stabilised, although numerous challenges remain. The East Timor conflict was finally resolved in 1999, after the territory voted for, and - after a bloody interlude - was finally granted independence. Aceh chose to stay within Indonesia after a 2005 peace agreement under which it became the only Indonesian province with the right to apply Sharia law. Other provinces have also been granted wide-ranging autonomy following sweeping reforms in 2000 that transformed Indonesia from a highly centralised country (Government, 2016).

The one part of Indonesia where separatist aspirations remain widespread is Papua. Under a 2012 law, the two provinces of Papua and West Papua enjoy even broader autonomy than other parts of the country. Further concessions have been made by current president Joko Widodo, who since 2015 has released dozens of Papuan separatists from jail (Jokowi's, 2017), lifted a ban on foreign journalists travelling to the territory, ${ }^{4}$ and promised more investment. In spite of this, a low-level insurgency continues, fuelled among other things by resentment at the failure of the region's economy to benefit from its natural resource wealth, and Indonesia's refusal to hold a credible referendum on independence (in a 1969 "Act of Free Choice," around 1000 Papuans hand-picked by the Indonesian army voted to join Indonesia). In September 2017 separatists claimed that $70 \%$ of the region's inhabitants had signed a petition calling for a free vote on independence (Banned, 2017); two months later they temporarily seized control over five villages (Armed, 2017).

Islamic terrorism is a serious potential threat in Indonesia. The country's bloodiest ever terrorist attack was the 2002 Bali bombing, which claimed over 200 victims. Some of the terrorists who carried out that attack were returnees from Afghanistan, where they had fought alongside Mujahideen rebels. The return of Indonesian jihadists

${ }^{4}$ However, in practice journalists still face restrictions; see for example: Indonesia Still Restricting, 2017. 
from Iraq and Syria risks fuelling a new wave of terrorism. Already, there have been several mostly small-scale attacks, of which the most serious in recent years was the Jakarta bombings of January 2016, which killed seven and injured two dozen (Islamic State, 2016). Responsibility for this and several similar incidents has been claimed by so-called Islamic State. Meanwhile, Jemaah Islamiya, the Al Qaida-linked group behind the 2002 Bali attack, is also showing signs of revival (As Indonesia, 2016).

Despite such concerns, so far the terrorist threat has been largely contained. Recent terrorist incidents have been mostly small-scale, with few casualties, suggesting that Indonesian jihadists lack the expertise or resources to launch more serious attacks. The number of jihadists is also relatively small; despite Indonesia having the world's largest Muslim population, Indonesia is only the 11th country of origin for Islamic State foreign fighters, behind several European countries including France and Germany (Benmelech, Klor, 2016). Furthermore, Indonesia's "Detachment 88 " counter-terrorist squad has proved remarkably effective, foiling multiple attempted attacks (Fighting, 2016).

Compared to terrorism, inter-communal tensions have a much broader impact. After peaking in the early 2000s, the intensity of violence has largely subsided, although there are recurrent frictions and occasional clashes between the country's main religious communities. Muslims have attacked Christians (for example in Aceh, where mobs burned down two churches in October 2015) and vice-versa. Particularly vulnerable are smaller religious minorities, such as Shia and Ahmadi Muslims (the vast majority of Indonesian Muslims, insofar as they identify with a particular sect at all, are Sunnis); in one particularly horrific incident in 2011, rioters in West Java stormed a house where Ahmadis were praying before bludgeoning and stoning three of them to death (The Persecution, 2011). One year later, a mob in East Java attacked a group of Shia school children and teachers, leaving two dead (Two Killed, 2012). Several thousand followers of the now-disbanded Gafatar sect lost their homes after their settlement in Indonesian Borneo was torched in January 2016 (Indonesia cracks, 2016). In all three incidents, the Indonesian authorities were accused of doing little to prevent violence or bring perpetrators to justice.

2017 has been one of the calmest years in recent history, with few violent incidents. Instead, it was the blasphemy trial of former Jakarta governor Basuki Tjahaja Purnama (popularly known as Ahok), against a backdrop of rising Islamic fundamentalism (Indonesia: Failure, 2018), that dominated the headlines. Among the hundreds of thousands who participated in huge rallies demanding a jail sentence for Ahok, a Chinese Protestant, were activists from the Islamic Defenders Front, a vigilante network that has carried out raids on venues such as nightclubs, brothels and massage parlours. The two-year sentence handed down to Ahok represents a major setback for religious tolerance in Indonesia.

\section{Why has Indonesia achieved greater stability than Myanmar?}

Despite starting out from similar initial conditions, Myanmar and Indonesia have developed in very different ways. Indonesia's story is a mostly encouraging one, particularly since the 1998-1999 democratic transition. Numerous challenges to stability remain, 
including Islamic fundamentalism, terrorism, Papuan separatism and inter-communal tensions. Nevertheless, most of these threats have been successfully contained, and Indonesia is now a democracy, in which the country's numerous religious and ethnic minorities harmoniously co-exist most of the time and in most regions.

Several factors can help to explain Indonesia's success. Among these are the country's centuries-old traditions of tolerance. Islam spread across the region through commerce rather than conquest, allowing it to co-exist peacefully alongside other religions. Traditional Indonesian "archipelago Islam" has accommodated numerous non-Islamic elements, such as the Hindu epics popular in Javanese culture. Such traditions made it logical for the country's founding fathers to envisage Indonesia as a multi-religious state based on tolerance rather than an Islamic Republic. In 1945 independence leader Sukarno enunciated the Pancasila, the five principles which became the basis for Indonesian statehood. Significantly, the first of these principles is belief in one Supreme God; though a Muslim, Sukarno refers to God and not Allah, implying acceptance of all monotheistic religions on an equal basis. For the purposes of Pancasila, Hinduism and Buddhism, both strongly represented in Indonesia, are considered as essentially monotheistic (Religious, 2016). Many other countries (including Myanmar) also enshrine religious freedom in their constitutions, but Indonesia stands out in the emphasis given to Pancasila, which is drummed into every schoolchild from an early age (Pancasila, 2017) and is ritualistically invoked by the country's religious and political leaders.

Continuity is another factor that has favoured Indonesia's development. Pancasila proved a stable foundation for Indonesian statehood that survived the country's numerous vicissitudes. Although it was in effect a military coup that brought Suharto to power, he kept the 1945 Constitution in place, together with the trappings of a civilian democracy. Under Suharto, the Pancasila not only survived as the official state ideology but even gained in importance thanks to an extensive indoctrination programme for school and university students, civil servants and military personnel (Cribb, 2010). Regular elections were held, though carefully stage-managed to prevent serious challenges to Suharto's rule. Thanks to this stable foundation, the transformation that followed Suharto's downfall was less of an upheaval than it might have been. The 1945 Constitution, with some amendments (for example, direct presidential elections), is still in force, and several Suharto-era parties survive.

Corrupt and autocratic though it was, the Suharto regime brought stability to Indonesia, following a relatively volatile period under post-independence leader Sukarno. Suharto normalised Indonesia's relations with its neighbours, kept inter-communal tensions under tight control, and oversaw a period of sustained economic growth.

Myanmar under its military junta was a very different story. A disastrous experiment with socialism turned the formerly prosperous country into one of the world's poorest; brutal repression inflamed ethnic tensions; sanctions imposed by the EU and United States following the junta's refusal in 1990 to recognise the results of a democratic election cut off ties with most of the international community. Since 2015, Myanmar finally has a democratically elected government, but the country remains bogged down in a never-ending cycle of violence, horrific human rights abuses, and fighting between the country's armed forces and ethnic minority rebels. All of these problems are to a 
large extent the direct results of the military's political role, which has been diminished but not ended by the 2008 Constitution.

In turn, the causes of disastrous military intervention in the country's politics can arguably be traced to the tragic assassination in 1947 of Aung San, leader of the country's independence movement and father of current de facto leader Aung San Suu Kyi. The death of Aung San was a serious setback to efforts to build a federal Burma accommodating the demands of ethnic minorities (Federalism, 2018), and thus set the scene for 15 years of civil war that were used by the military as a pretext for its 1962 coup. But for that tragic event, Myanmar might have had a different and happier postindependence history.

\section{Can Myanmar follow Indonesia's successful example?}

Indonesia has already played an important role in promoting democratic reforms in Myanmar. In 2007, former President Yudhoyono sent retired General Agus Widjojo to persuade the country's junta to embark on reforms (Asian, 2016), and the success of Indonesia's democratic transition remains an encouraging example for Myanmar.

However, the destructive role played by the Myanmar military means that the country's prospects for following that example depend, among other things, on reforms that will finally bring the armed forces under civilian control. In view of the military's constitutional veto, such reforms will require its consent. Military Commander-in-Chief Min Aung Hlaing has stated that the military could only contemplate stepping back from politics if peace deals can be reached with all the country's ethnic armed groups (Myanmar's, 2015). Myanmar therefore remains locked in a Catch-22 situation - military violence is likely to perpetuate ethnic conflicts, but until those conflicts are resolved, civilian authorities will be powerless to curb violence.

\section{REFERENCES}

Armed separatists occupy villages near Freeport's Indonesia mine, Reuters, 9 November 2017, https://www.reuters.com/article/us-indonesia-freeport-security/armed-separatists-occupyvillages-near-freeports-indonesia-mine-idUSKBN1D917K?il=0.

As Indonesia hunts down Islamic State, homegrown jihadis regroup, Reuters, 15 February 2016, https:// www.reuters.com/article/us-indonesia-security/as-indonesia-hunts-down-islamic-statehomegrown-jihadis-regroup-idUSKCN0VO03Y?feedType=RSS\&feedName=worldNews.

Asian Support for Democracy in Myanmar, Ichihara M. et al, Carnegie Endowment for International Peace, October 2016, http://carnegieendowment.org/2016/10/19/asian-support-for-democracy-in-myanmar-pub-64875.

Banned West Papua independence petition handed to UN, "The Guardian", 27 September 2017, https://www.theguardian.com/world/2017/sep/27/banned-west-papua-independence-petition-un. 
Benmelech E., Klor E. (2016), What Explains the Flow of Foreign Fighters to Isis?, "National Bureau of Economic Research", Working Paper 22190, http://www.nber.org/papers/w22190. pdf.

Burma/Myanmar Military Aggression Violates the Nationwide Ceasefire Agreement and Endangers Villagers in Mutraw District, Karen State, Progressive Voice, 9 March 2018, https://progressivevoicemyanmar.org/2018/03/09/burma-myanmar-military-aggression-violates-thenationwide-ceasefire-agreement-and-endangers-villagers-in-mutraw-district-karen-state/.

Central Intelligence Agency World Factbook: Burma, https://www.cia.gov/library/publications/theworld-factbook/geos/bm.html.

Cribb R. (2010), The Historical Roots of Indonesia's New Order: Beyond the Colonial Comparison, in: Soeharto's New Order and its Legacy. Essays in honour of Harold Crouch, (eds.) E. Aspinall, G. Fealy, Canberra.

Federalism and State Formation in Myanmar, The Irrawaddy, 14 February 2018, https:/www.irrawaddy.com/opinion/guest-column/federalism-and-state-formation-in-myanmar.html.

Fighting back: How Indonesia's elite police turned the tide on militants, Reuters, 23 December 2016, https://www.reuters.com/article/us-indonesia-security/fighting-back-how-indonesias-elitepolice-turned-the-tide-on-militants-idUSKBN14C0X3.

Government Decentralization Program in Indonesia, Nasution A., Asian Development Bank Institute, October 2016, https://www.adb.org/sites/default/files/publication/201116/adbi-wp601.pdf.

Govt Publishes Data on Populations of Religious Groups, The Irrawaddy, 21 July 2016, https:// www.irrawaddy.com/news/burma/govt-publishes-data-on-populations-of-religious-groups. html.

In Bangladesh refugee camps, the nascent Rohingya insurgency commands support and sows fear, IRIN, 27 November 2017, https://www.irinnews.org/feature/2017/11/27/bangladesh-refugee-camps-nascent-rohingya-insurgency-commands-support-and-sows.

In the name of food security, Inside Indonesia, 9 January 2017, http://www.insideindonesia.org/inthe-name-of-food-security.

Indonesia cracks down on 'deviant sect' Gafatar after village burned down by mob, Sydney Morning Herald, 25 January 2016, https://www.smh.com.au/world/indonesia-cracks-down-on-deviant-sect-gafatar-after-village-burned-down-by-mob-20160125-gmdj11.html.

Indonesia: Failure to Confront Intolerance: Vulnerable Communities Face Worsening Risk, Human Rights Watch, 18 January 2018, https://www.hrw.org/news/2018/01/18/indonesia-failureconfront-intolerance.

Indonesia Still Restricting Foreign Media From Papua, Human Rights Watch, 8 May 2017, https:// www.hrw.org/news/2017/05/08/indonesia-still-restricting-foreign-media-papua.

Indonesian 2010 census, http://sp2010.bps.go.id/files/ebook/kewarganegaraan\%20penduduk\%20indonesia/index.html (in Indonesian).

Indonesia's defence minister hits back in communist massacre row, South China Morning Post, 2 June 2016, http://www.scmp.com/news/asia/southeast-asia/article/1962635/indonesiasdefence-minister-hits-back-communist-massacre.

Indonesia's military will be less politicised, Oxford Analytica, 1 February 2018, https://dailybrief. oxan.com/Analysis/DB229481/Indonesias-military-will-be-less-politicised-.

Islamic State Attack in Indonesia? A Look at the 2016 Jakarta Bombings, 15 January 2016, https:// thediplomat.com/2016/01/islamic-state-attack-in-indonesia-a-look-at-the-2016-jakartabombings/.

Jade: Myanmar's “Big State Secret”, Global Witness, 23 October 2015, https://www.globalwitness. org/en/campaigns/oil-gas-and-mining/myanmarjade/. 
Jokowi's Political Prisoner Problem, Human Rights Watch, 9 August 2017, https://www.hrw.org/ news/2017/08/09/jokowis-political-prisoner-problem.

Military Marching Out of Parliament - for Good, InterPress Service News Agency, 12 April 2004, http://www.ipsnews.net/2004/04/politics-indonesia-military-marching-out-of-parliamentfor-good/.

Myanmar: Ethnic minorities face range of violations including war crimes in northern conflict, Amnesty International, 14 June 2017, https://www.amnesty.org/en/latest/news/2017/06/myanmar-ethnic-minorities-face-violations-in-northern-conflict/.

Myanmar events 'bear hallmarks of genocide': UN expert, AFP, 12 March 2018, https://www.afp. com/en/news/23/myanmar-events-bear-hallmarks-genocide-un-expert-doc-12d8oq4.

Myanmar faces danger from Islamic State militants, Malaysian police say, Reuters, 4 January 2017, https://www.reuters.com/article/us-malaysia-security-rohingya/myanmar-faces-dangerfrom-islamic-state-militants-malaysian-police-say-idUSKBN14O0PX.

Myanmar's strongman gives rare BBC interview, BBC News, 20 July 2015, http://www.bbc.com/ news/world-asia-33587800.

Pancasila should become subject at school: Association, Jakarta Post, 3 June 2017, http://www.thejakartapost.com/news/2017/06/03/pancasila-should-become-subject-at-school-association. html.

Religious pluralism in Indonesia, Russell M., European Parliamentary Research Service, May 2016, http://www.europarl.europa.eu/RegData/etudes/BRIE/2016/582045/EPRS_BRI(2016) 582045_EN.pdf.

The Persecution of Indonesia's Ahmadi Muslims, Newsweek, 13 February 2011, http://www.newsweek.com/persecution-indonesias-ahmadi-muslims-68737.

Truth and Reconciliation in Indonesia, The New York Times, 21 April 2016, https://www.nytimes. com/2016/04/21/opinion/truth-and-reconciliation-in-indonesia.html.

Two Killed as Hard-liners Attack Shia School Group, Jakarta Globe, 27 August 2012, http://jakartaglobe.id/archive/two-killed-as-hard-liners-attack-shia-school-group/.

\begin{abstract}
For most of the former European colonies of South and Southeast Asia, the end of the Second World War was also the beginning of the end of colonial rule. With independence came the challenge of unifying disparate ethnic, religious and linguistic communities into cohesive nations - a challenge that some countries met more successfully than others. The price of failure could be high - hundreds of thousands were killed, and many millions displaced in 1947, as inter-communal conflicts tore British India apart. Indonesia declared independence in 1945 (a declaration not recognised by the country's Dutch colonial rulers until 1949), while Burma (as Myanmar was then known) was granted independence by Britain in 1948. Both countries were able to avoid tragedies on the scale of the Indian Partition. Nevertheless, nation-building has been a difficult and as yet uncompleted process, the source of continuing challenges to national security. This article looks at the situation in the two countries, traces the origins of some of the current problems, and attempts to explain why Indonesia has generally been more successful in this respect than Myanmar, despite the similarities in the initial situations of the two countries.
\end{abstract}

Keywords: Indonesia, Myanmar, nation building, ethnic minorities, democratic transition 


\title{
HISTORIA DWÓCH PAŃSTW: BUDOWANIE NARODÓW I WYZWANIA DLA BEZPIECZEŃSTWA W INDONEZJI I MYANMARZE
}

\begin{abstract}
STRESZCZENIE
Dla większości byłych kolonii europejskich w Południowej i Południowo-wschodniej Azji, zakończenie drugiej wojny światowej było również początkiem końca rządów kolonialnych. Wraz z niepodległością pojawiło się wyzwanie połącznia społeczności odmiennych etnicznie, religijnie i językowo - wyzwanie, z którym jedne państwa poradziły sobie lepiej niż pozostałe. Cena porażki była wysoka: setki tysięcy zabitych, miliony przesiedlonych w 1947 r., gdy wewnętrzne konflikty rozdarły Brytyjskie Indie. Indonezja ogłosiła niepodległość w 1945 r. (deklaracji tej nie uznawały holenderskie władze kolonialne aż do 1949 r.), podczas gdy Birma (Myanmar) uzyskała niepodległość w 1948 r. Oba państwa uniknęły tragedii na miarę podziału Indii Brytyjskich. Jednak budowanie narodów było trudne i nadal - jako proces nieukończony - stanowi wyzwanie dla bezpieczeństwa. Artykuł analizuje sytuację w obu państwach, wskazuje źródła obecnych problemów i poszukuje odpowiedzi na pytanie dlaczego - pomimo podobieństw sytuacji wyjściowych - Indonezja poradziła sobie lepiej na drodze budowy narodu.
\end{abstract}

Słowa kluczowe: Indonezja, Myanmar, mniejszości etniczne, tranzycja demokratyczna 
